\title{
Chemistry and kinetics of the pyrophoric plutonium hydride-air reaction
}

\author{
John M. Haschke ${ }^{1}$, Long N. Dinh ${ }^{2 *}$ \\ 1. Actinide Science Consulting, College Station, TX, USA: 2. Lawrence Livermore National Laboratory, \\ Livermore, CA, USA \\ * Corresponding author. Address: Lawrence Livermore National Laboratory, Mail Stop L-091, P.O. Box \\ 808, Livermore, CA, USA; Tel. +1 925422 4271; E-mail: Dinh1@1lnl.gov
}

\begin{abstract}
The chemistry and kinetics of the pyrophoric reaction of the plutonium hydride solid solution $\left(\mathrm{PuH}_{\mathrm{x}}, 1.9 \leq \mathrm{x} \leq 3\right)$ are derived from pressure-time and gas analysis data obtained after exposure of $\mathrm{PuH}_{2.7}$ to air in a closed system. The reaction is described by two sequential steps that result in reaction of all $\mathrm{O}_{2}$, partial reaction of $\mathrm{N}_{2}$, and formation of $\mathrm{H}_{2}$. Hydrogen formed by indiscriminate reaction of $\mathrm{N}_{2}$ and $\mathrm{O}_{2}$ at their 3.71:1 molar ratio in air during the initial step is accommodated as $\mathrm{PuH}_{3}$ inside a product layer of $\mathrm{Pu}_{2} \mathrm{O}_{3}$ and $\mathrm{PuN} . \mathrm{H}_{2}$ is formed by reaction of $\mathrm{O}_{2}$ and partial reaction of $\mathrm{N}_{2}$ with $\mathrm{PuH}_{3}$ during the second step. Both steps of reaction are described by general equations for all values of $\mathrm{x}$. The rate of the first step is proportional to the square of the $\mathrm{O}_{2}$ pressure, but independent of temperature, $\mathrm{x}$, and $\mathrm{N}_{2}$ pressure. The second step is a factor of ten slower than step one with its rate controlled by diffusion of $\mathrm{O}_{2}$ through a boundary layer of product $\mathrm{H}_{2}$ and unreacted $\mathrm{N}_{2}$. Rates and enthalpies of reaction are presented and anticipated effects of reactant configuration on the heat flux are discussed.
\end{abstract}




\section{Introduction}

The pyrophoric reactions of plutonium hydride and partially hydrided plutonium metal are of continuing concern because of associated thermal and dispersal hazards [1]. An exothermic reaction of the cubic solid-solution hydride $\left(\mathrm{PuH}_{\mathrm{x}}, 1.9 \leq \mathrm{x} \leq 3\right)$ initiates spontaneously upon exposure to air at room temperature. The corrosion rate of $\mathrm{Pu}$ in dry air is limited by diffusion of oxygen through a surface layer of $\mathrm{PuO}_{2}$. The rate is catalytically increased by a factor of $10^{10}$ if the metal surface is coated with hydride. Aerosolizable and respirable particles are formed by an autocatalytic reaction in which an $\alpha-\mathrm{Pu}_{2} \mathrm{O}_{3}$ layer formed by oxidation of the $\mathrm{PuH}_{\mathrm{x}}$ surface promotes disproportionation of adsorbed $\mathrm{O}_{2}$ and $\mathrm{N}_{2}$, and facilitates transport of the resulting $\mathrm{O}^{2-}$ and $\mathrm{N}^{3-}$ ions to the product-metal interface [1]. Reaction of oxygen and the concurrent $\mathrm{Pu}_{2} \mathrm{O}_{3}$-catalyzed reaction of nitrogen in air at 1 bar penetrate the metal at a combined linear rate of $1 \mathrm{~mm}$ $\min ^{-1}$ until all the $\mathrm{Pu}$ is consumed. Concern about the thermal hazards posed by the reactions of hydride and metal is compounded because the heats of those reaction are released in sharp spikes, not at rates that allow heat to dissipate with a modest temperature excursion. During exposure of hydride-coated metal to $\mathrm{O}_{2}$ or air at low $\mathrm{O}_{2}$ partial pressure ( $<50 \mathrm{mbar}$ ), the temperature rise at the sample surface is insufficient for maintaining the catalytic $\mathrm{Pu}_{2} \mathrm{O}_{3}$ surface. The resulting formation of a $\mathrm{PuO}_{2}$ surface layer forces the reaction into a slow diffusion-controlled kinetic regime [1] with thermal consequences that are negligible and beyond the scope of this study.

The chemistry and kinetics of $\mathrm{PuH}_{\mathrm{x}}$-coated $\mathrm{Pu}$ with $\mathrm{O}_{2}$ and air at 1 bar are described in prior reports [1-3]. In these cases, the rates of the catalyzed reactions are independent of temperature $\left(\mathrm{E}_{\mathrm{a}}=0\right)$ and proportional to the square of the $\mathrm{O}_{2}$ pressure [1]. Hydrogen is not formed as a gaseous product, but is accommodated as a $\mathrm{PuH}_{3}$ core within a shell of $\mathrm{Pu}_{2} \mathrm{O}_{3}$ formed by reaction of $\mathrm{O}_{2}$ or within a shell of $\mathrm{Pu}_{2} \mathrm{O}_{3}+\mathrm{PuN}$ formed by indiscriminate reaction of $\mathrm{N}_{2}$ and $\mathrm{O}_{2}$ at the 3.71:1 ratio of those gases in air. In contrast to these observations for reaction of hydride-coated $\mathrm{Pu}$, results show that exposure of $\mathrm{PuH}_{\mathrm{x}}$ to air produces substantial amounts of $\mathrm{H}_{2}$ and that consumption of $\mathrm{N}_{2}$ is incomplete [2]. Hydride and unreacted air remain after the $\mathrm{PuH}_{\mathrm{x}}$-catalyzed reaction of metal is complete, but continuing reaction with the release of $\mathrm{H}_{2}$ is not observed. Resolution of this difference in behavior of $\mathrm{PuH}_{\mathrm{x}}$-coated $\mathrm{Pu}$ and $\mathrm{PuH}_{\mathrm{x}}$ is needed because formation of hydrogen expands the hazardous potential of the $\mathrm{PuH}_{\mathrm{x}}$-air reaction.

The kinetics of a corrosion reaction is an important consideration in hazard assessment because it determines the rates at which dispersible particles form and heat is produced. The nuclear material hazards posed by corrosion of plutonium during exposure to air are addressed in a report on particle-size distributions of products [2]. Promotion of the corrosion rate by hydride on the metal surface was observed and kinetics of the $\mathrm{PuH}_{\mathrm{x}^{-}}$ catalyzed reaction of $\mathrm{Pu}$ metal were determined. The reaction of hydride particles with air was also investigated and experimental data were reported, but neither the chemistry nor the kinetics of the complex reaction was determined. Here, we use rate data collected during the earlier study [2] to quantify the chemistry and kinetics of the $\mathrm{PuH}_{\mathrm{x}}$-air reaction 
and to identify factors that determine hydride pyrophoricity and the extents of heat generation for different reactant configurations.

\section{Experimental methods}

Multiple experiments were conducted to investigate the reaction of plutonium hydride with air at $25^{\circ} \mathrm{C} . \mathrm{PuH}_{\mathrm{x}}$ samples $(25.0 \mathrm{~g})$ were prepared by reacting Ga-stabilized $\delta$-phase $\mathrm{Pu}$ with excess $\mathrm{H}_{2}$ at pressures of 3-4 bar in a stainless steel reactor (0.040 1) fitted with a pressure transducer. After cooling to $25^{\circ} \mathrm{C}$ and evacuation to $10^{-6} \mathrm{mbar}$, the reactor was filled with air by expansion from a pressurized (1.04 bar) reservoir (2.78 1) to a theoretical initial pressure of 1.01 bar. The pressure of the combined system and the gasphase temperature were measured over time. The reactor and reservoir were isolated after completion of the reaction and gas samples from those volumes were analyzed by mass spectrometry.

Use of experimental conditions and observations to derive essential properties of the $\mathrm{PuH}_{\mathrm{x}}$ products is necessary because determinations of $\mathrm{x}$ and the particle-size distribution were precluded by the possibility of pyrophoric reaction during handling outside the Arfilled glovebox. Since hydrides with $\mathrm{x}$ values near 3 are stable at room temperature only if the equilibrium hydrogen pressure is present $[4,5]$, the products would have readily lost $\mathrm{H}_{2}$ until $\mathrm{x}$ reached 2.7 during evacuation to remove unreacted $\mathrm{H}_{2}$ at $25^{\circ} \mathrm{C}$ [6]. The sizes of $\mathrm{PuH}_{\mathrm{x}}$ particles formed by the $\mathrm{Pu}-\mathrm{H}_{2}$ reaction increase as the pressure-dependent rate increases $[1,3]$ and relatively coarse products are expected at the preparative conditions. Since the size distribution and specific area of the hydride might be changed by spallation of product during the reaction with air, residues from air-exposure tests were compared with samples of unreacted hydride in the inert-atmosphere glovebox. Particle sizes $(0.1-1.0 \mathrm{~mm})$ were not observably altered by spallation. A geometric area of $11.5 \pm 1.5 \mathrm{~cm}^{2} \mathrm{~g}^{-1}$ is calculated for a hydride comprised of $0.5-\mathrm{mm}$-diameter particles. The molecular-scale (Braunauer-Emmett-Teller, BET) specific area of $230 \pm 30 \mathrm{~cm}^{2} \mathrm{~g}^{-1}$ is obtained using an experimental result showing that the BET area obtained by adsorption of $\mathrm{Ar}$ at $-196{ }^{\circ} \mathrm{C}$ is a factor of 20 greater than the geometric area [1].

\section{Results and discussion}

\subsection{Chemistry}

As shown by a typical gas pressure-time (P-t) curve (Figure 1) published previously [2], attainment of an initial pressure near 1.0 bar immediately after expansion of air into the reactor was followed by a v-shaped pressure variation that was identified as a consequence of experimental design. The pressure measured in the reactor decreased sharply over a 0.05 min period and increased to a value greater than 1 bar during the following 0.05 min period as the gas-phase temperature increased to approximately $150^{\circ} \mathrm{C}$. A stable pressure of $1.00 \pm 0.01$ bar was reached after the reactor had cooled. Gas analysis showed a mixture of $75 \% \mathrm{H}_{2}$ and $25 \% \mathrm{~N}_{2}$ in the reactor and $7 \% \mathrm{H}_{2}$ in the air reservoir. Data for all tests show that $\mathrm{N}_{2}$ and $\mathrm{O}_{2}$ were consumed at an average molar ratio 
of 1.6 $\pm 0.5: 1$ until pressurization of the reactor by product $\mathrm{H}_{2}$ and unreacted $\mathrm{N}_{2}$ prevented entry of additional air from the reservoir.

The formation of $\mathrm{H}_{2}$ during rapid exposure of $\mathrm{PuH}_{\mathrm{x}}$ to air suggests that, unlike the other hydride-catalyzed reactions [1], product $\mathrm{H}$ may not be accommodated as $\mathrm{PuH}_{3}$ in the solid. The reaction products for $\mathrm{PuH}_{2.7}$ are accurately described by two sequential steps (Eqns. 1 and 2, Table 1) that forms the trihydride before continuing reaction yields the net products (Eqn. 3). The net reaction agrees with the single-step reaction (Eqn. 4) that forms $\mathrm{H}_{2}$ by direct reaction of $\mathrm{PuH}_{2.7}$. For both pathways, the theoretical composition (74\% product $\mathrm{H}_{2}, 26 \%$ unreacted $\mathrm{N}_{2}$ ) of the final gas mixture agrees with the experimental results. Although $\mathrm{N}_{2}$ and $\mathrm{O}_{2}$ are consumed at the 3.71:1 ratio of air in Eqn. 1 , their consumption at a lower ratio (1.5:1) during the second step is necessary to give a net value of 1.6:1. General formula describing the two-step sequence (Eqns. 5-7) and the single-step reaction (Eqn. 8) for all compositions of the cubic $\mathrm{PuH}_{\mathrm{x}}$ solid solution are also given in Table 1. The predicted $\mathrm{N}_{2}: \mathrm{O}_{2}$ reaction ratio is $1.6: 1$ for all $\mathrm{x}$ values using Eqn. 8, but progressively decreases from 1.9 to 1.5 as $x$ increases from 2 to 3 if Eqn. 7 is used.

Accurate description of chemistry for the $\mathrm{PuH}_{\mathrm{x}}$ - air reaction is contingent on determining if the process occurs via the single-step or the two-step pathway. For $\mathrm{x}=2$, the $\Delta \mathrm{G}^{\mathrm{o}}$ values derived from Gibbs energies of formation [1] show that Eqn. $8(-298 \mathrm{~kJ}$ $\left.\mathrm{mol}^{-1}\right)$ is more favorable than Eqn. $5\left(-86 \mathrm{~kJ} \mathrm{~mol}^{-1}\right)$, but the observed path of a reaction is determined by kinetics. After $\mathrm{H}$ is formed by reaction of air, its movement into the underlying $\mathrm{PuH}_{\mathrm{x}}$ should be facile relative to hydrogen formation that requires countercurrent transport of $\mathrm{H}$ to the surface and diffusion of $\mathrm{H}_{2}$ through the reacting gas. Formation of $\mathrm{PuH}_{3}$ is facilitated by rapid movement of $\mathrm{H}$ in $\mathrm{PuH}_{\mathrm{x}}$, a superionic conductor with highly mobile $\mathrm{H}$ [1]. The $\mathrm{v}$-shaped time dependence of reactor pressure is consistent with a two-step process of pressure loss and gain, but not with Eqn. 4 in which each mole of air forms $2.35 \mathrm{~mol}$ of $\mathrm{H}_{2}$. Indiscriminate reaction of $\mathrm{O}_{2}$ and $\mathrm{N}_{2}$ is observed for adherent $\mathrm{PuH}_{\mathrm{x}}$ on $\mathrm{Pu}$ and is expected during the initial reaction between particulate hydride and air. However, consumption of air at a $\mathrm{N}_{2}: \mathrm{O}_{2}$ ratio less than 3.71:1 during the first step of the $\mathrm{PuH}_{\mathrm{x}}$-air reaction merits consideration. Calculations for the case in which $10 \%$ of the $\mathrm{N}_{2}$ did not react show that the pressure of accumulated $\mathrm{N}_{2}$ in the reactor would reach 0.99 bar when reaction of the hydride was only $43 \%$ complete and $\mathrm{x}$ of the $\mathrm{PuH}_{\mathrm{x}}$ was 2.8 . Complete reaction of $\mathrm{O}_{2}$ and $\mathrm{N}_{2}$ during an initial step of the $\mathrm{PuH}_{\mathrm{x}}$-air reaction is implied because the extent of air consumption shown by Fig. 1 and the high $\mathrm{H}_{2}$ percentage found in the residual gas after over-pressurization of the reactor are contingent on complete consumption of air during the initial step or reaction.

\subsection{Kinetics}

Identification of a two-step path for the $\mathrm{PuH}_{2.7}$-air reaction is confirmed by using the P-t data to derive kinetic properties. Results are evaluated assuming that the reaction proceeds by indiscriminate consumption of $\mathrm{O}_{2}$ and $\mathrm{N}_{2}$ (Eqn. 1) during the descending segment of the v-shaped P-t curve and to formation of $\mathrm{H}_{2}$ by further reaction of product $\mathrm{PuH}_{3}$ with air (Eqn. 2) during the ascending segment. Occurrence of Eqn. 1 during the initial step of reaction is consistent with indiscriminate reaction of $\mathrm{O}_{2}$ and $\mathrm{N}_{2}$ during 
reaction of $\mathrm{PuH}_{\mathrm{x}}$-coated $\mathrm{Pu}$ with air. Results of PVT and gas-analyses for the reactor and reservoir show that $9.1 \mathrm{mmol}$ of $\mathrm{H}_{2}$ was formed. Eqn. 2 shows that $3.5 \mathrm{mmol}$ of air would have reacted during step two. The amount of air consumption via Eqn. 1 is the difference between the final moles of gas in the system and the calculated net increase in moles of gas $(5.6 \mathrm{mmol})$ during the second step. Since the initial and final system pressures were identical (1.0 bar), $5.6 \mathrm{mmol}$ of air reacted during the first step. According to Eqn. 1, that amount of air would have consumed $0.1047 \mathrm{~mol}(25.3 \mathrm{~g})$ of $\mathrm{PuH}_{2.7}$. The calculated rate, $\mathrm{R}$, is $0.087 \pm 0.009 \mathrm{~g} \mathrm{PuH}_{2.7} \mathrm{~cm}^{-2} \mathrm{~min}^{-1}$ in air at 1 bar pressure. Studies show that the reaction rates of $\mathrm{PuH}_{\mathrm{x}}$-coated $\mathrm{Pu}$ with $\mathrm{O}_{2}$ /air and $\mathrm{PuH}_{\mathrm{x}}$ with $\mathrm{O}_{2}$ are independent of temperature, $\mathrm{P}_{\mathrm{N} 2}$, and $\mathrm{x}$, but proportional to $\left(\mathrm{P}_{\mathrm{O} 2 / \mathrm{air}}\right)^{2}$ [1]. If those dependencies are applied to $\mathrm{PuH}_{\mathrm{x}}$-air, the rate of Eqn. 1 is:

$$
\mathrm{R}\left(\text { in } \mathrm{g} \mathrm{PuH}_{\mathrm{x}} \mathrm{cm}^{-2} \mathrm{~min}^{-1}\right)=0.087\left(\mathrm{P}_{\mathrm{air}}\right)^{2}(\mathrm{P} \text { in bar, BET area). }
$$

Comparison of the rate constants for the general rate equation, $\mathrm{R}=\mathrm{C}\left(\mathrm{P}_{\mathrm{O} 2}\right)^{2}$, for the hydride-catalyzed reactions of $\mathrm{O}_{2}$ /air with $\mathrm{PuH}_{\mathrm{x}}$-coated $\mathrm{Pu}$ and $\mathrm{PuH}_{\mathrm{x}}$ shows (Table 2) that kinetic behavior is related in two ways. The ratio of $\mathrm{C}(\mathrm{Pu}): \mathrm{C}\left(\mathrm{PuH}_{\mathrm{x}}\right)$ is 20 , the factor by which the BET area of the $\mathrm{PuH}_{\mathrm{x}}$ layer on the $\mathrm{Pu}$ exceeds the geometric area of the hydride-coated sample [1]. In a more complex way, the values of $\mathrm{C}$ (air) for $\mathrm{Pu}$ and $\mathrm{PuH}_{\mathrm{x}}$ are a factor of $0.23-0.24$ less than the corresponding values for $\mathrm{C}\left(\mathrm{O}_{2}\right)$. The energetically favorable $\mathrm{Pu}-\mathrm{N}_{2}$ reaction is sluggish at temperatures above $1000{ }^{\circ} \mathrm{C}$ [7] and $\mathrm{N}_{2}$ is used as inert atmosphere for handling $\mathrm{Pu}$, but $\mathrm{PuH}_{\mathrm{x}}$-catalyzed nitriding via Eqn. 5 consumes hydride at a rate that is 5.57 times faster than the simultaneous rate of hydride consumption by $\mathrm{O}_{2}$. If $\mathrm{R}$ is independent of $\mathrm{P}_{\mathrm{N} 2}$, replacement of oxygen at 1 bar by air at 1 bar should decrease the rate by a factor of 0.246 , the net result of the 5.57-fold increase in $\mathrm{Pu}$ consumption and the decrease of $(0.21)^{2}$ due to the lower $\mathrm{P}_{\mathrm{O} 2}$. Prediction of $\mathrm{C}$ for the $\mathrm{PuH}_{\mathrm{x}}$-air reaction using experimental $\mathrm{C}$ ratios for the reactions of $\mathrm{PuH}_{\mathrm{x}}$-coated $\mathrm{Pu}$ with $\mathrm{O}_{2}$ /air and $\mathrm{PuH}_{\mathrm{x}}$ with $\mathrm{O}_{2}$ (Table 2) both gives values of 0.085 for Eqn. 9.

Kinetic results confirm that the reactions of $\mathrm{PuH}_{\mathrm{x}}$ and $\mathrm{PuH}_{\mathrm{x}}$-coated $\mathrm{Pu}$ with $\mathrm{O}_{2}$ or air proceed via the same reaction sequence that forms a core of $\mathrm{PuH}_{3}$ inside a product layer of $\mathrm{Pu}_{2} \mathrm{O}_{3}$ or $\mathrm{Pu}_{2} \mathrm{O}_{3}+\mathrm{PuN}$. A conceptual description of the process for $\mathrm{PuH}_{\mathrm{x}}$-air is presented schematically in Figure 2. The proposed mechanism accounts for appearance of the v-shaped P-t curve in Figure 1. The air pressure instantly rose to near 1 bar while onset of Eqn. 1 was briefly delayed by formation of the catalytic $\mathrm{Pu}_{2} \mathrm{O}_{3}$ surface layer on $\mathrm{PuH}_{2.7}$. The subsequent rate of air consumption by the reaction exceeded the rate of air flow into the reactor and the transient pressure in the reactor steadily decreased until the initial step of reaction was complete. During the reaction of hydride-coated plutonium with $\mathrm{O}_{2}$ or air, product $\mathrm{H}$ is rapidly transported to the hydride-metal interface, forms hydride until the metal is consumed, and ultimately transforms the hydride core to $\mathrm{PuH}_{3}$. Characterization of the hydride-Pu interface $[8,9]$ at slow hydriding rates show that a two-phase (hydride + metal) zone is formed as $\mathrm{H}$ penetrates the metal and suggests that a similar intermediate layer may exist during the rapid macroscopic reaction of $\mathrm{PuH}_{\mathrm{x}^{-}}$ coated $\mathrm{Pu}$ with air. The product layers obtained with coated metal are inherently thicker than those obtained with hydride particles.

The derived rate for $\mathrm{PuH}_{3}$-air (Eqn. 2) is a factor of ten slower than that for the $\mathrm{PuH}_{2.7}$-air reaction. Formation of $9.1 \mathrm{mmol} \mathrm{H}_{2}$ during the $0.05 \mathrm{~min}$ period of reaction 
consumed $1.47 \mathrm{~g}(\sim 6 \%)$ of the trihydride before being stopped by pressurization of the reactor. The derived $\mathrm{R}$ value is $0.0051 \mathrm{~g} \mathrm{PuH}_{3} \mathrm{~cm}^{-2} \mathrm{~min}^{-1}$ (BET area). The kinetic effects of temperature, gas concentrations, and extent of reaction are not known.

Formation of $\mathrm{H}_{2}$ via Eqn. 6 is a unique feature of the $\mathrm{PuH}_{\mathrm{x}}$-air reaction and examination of a likely reason for that behavior is merited. The thickness of the product layer encasing the $\mathrm{PuH}_{3}$ is determined by sample area, the extent of Eqn. 1, and x, with the value approaching zero as $x$ approaches 3 . The average calculated thickness of the $\mathrm{Pu}_{2} \mathrm{O}_{3}+\mathrm{PuN}$ layer formed during the test with $\mathrm{PuH}_{2.7}$ is $\sim 400 \mathrm{~nm}$. Thicknesses varied from $\sim 80 \mathrm{~nm}$ for $0.1-\mathrm{mm}$-diameter particles to $\sim 800 \mathrm{~nm}$ for particles with diameters of $1.0 \mathrm{~mm}$. Transport of $\mathrm{O}$ and $\mathrm{N}$ to the underlying $\mathrm{PuH}_{3}$ and countercurrent movement of product $\mathrm{H}$ to the surface are necessary for reaction. Failure to observe $\mathrm{H}_{2}$ after relatively thick $(0.5-1.0 \mathrm{~mm})$ product layers were formed during the reactions of $\mathrm{PuH}_{\mathrm{x}}$-coated $\mathrm{Pu}$ with $\mathrm{O}_{2}$ [1] or air is consistent with limitation of those transport processes. Transport through a $\mathrm{Pu}_{2} \mathrm{O}_{3}+\mathrm{PuN}$ layer formed by air may also be more favorable than through the $\mathrm{Pu}_{2} \mathrm{O}_{3}$ layer formed by $\mathrm{O}_{2}$ because of differences in morphology of the layers. The porosity of a mixed-phase product comprised of small oxide and nitride grains is likely to be greater than that of a single-phase product in which growth of larger grains is possible.

\subsection{Thermal hazards}

The heat flux generated by reaction of air with $\mathrm{PuH}_{\mathrm{x}}$ is determined by the kinetics and thermodynamics of hydriding. As outlined in Table 3, a progressive decrease in heat production via Eqn. 5 with increasing $\mathrm{x}$ is accompanied by an increase in the heat for the second step (Eqn. 6). $\Delta \mathrm{H}^{\mathrm{o}}$ values for the net reaction vary by less than $10 \%$ over the composition range of $\mathrm{PuH}_{\mathrm{x}}$. Occurrence of the reaction for $\mathrm{x}$ greater than 2.7 at room temperature is unlikely due to spontaneous loss of $\mathrm{H}_{2}$ at higher compositions. The enthalpies for all reactions are linear functions of $\mathrm{x}$ and readily derived by interpolation.

Results of this study demonstrate that the extent of heat generation may be limited by physical constraints. Such behavior was observed in this study when reaction ceased because the reactor was pressurized above 1 bar by product $\mathrm{H}_{2}$ and unreacted $\mathrm{N}_{2}$. Eqn. 7 shows that a standard liter of gas mixture is formed by the reaction of air with $7 \mathrm{~g}$ of $\mathrm{PuH}_{2}$. In the case of a containment breach for a system or vessel containing hydride, the likelihood of a large thermal excursion may be substantially diminished if the $\mathrm{PuH}_{\mathrm{x}}$-air reaction is throttled by the rate at which air reaches the hydride [1].

Reaction of unconfined $\mathrm{PuH}_{\mathrm{x}}$ in air is complex and presents significant potential for a thermal excursion if the hydride is disturbed. The reaction initiates spontaneously and is evidenced by a pale blue flame at a distance of $1-2 \mathrm{~cm}$ above the solid $[1,10]$. That observation is consistent with burning of product $\mathrm{H}_{2}$ formed by Eqn. 6. Formation of the $\mathrm{Pu}_{2} \mathrm{O}_{3}$ catalyst and initiation of the $\mathrm{H}_{2}-\mathrm{O}_{2}$ reaction are promoted by heat from step one. However, reaction of the $\mathrm{PuH}_{3}$ product via Eqn.6 apparently depends on the thickness of the surface product. Reaction of the trihydride is likely because the calculated thickness $(\sim 100 \mathrm{~nm})$ of the $\mathrm{Pu}_{2} \mathrm{O}_{3}+\mathrm{PuN}$ layer formed during reaction of $\mathrm{PuH}_{2}$ powder $(0.20 \pm 0.05$ $\mathrm{m}^{2} \mathrm{~g}^{-1} \mathrm{BET}$ area) prepared by slow reaction at low temperature and low $\mathrm{H}_{2}$ pressure [1] is 
a factor of four less than that for $\mathrm{PuH}_{2.7}$ sample in this study. $\Delta \mathrm{H}^{\mathrm{o}}$ values for Eqn. 6 (Table 3) are increased by the production of additional heat from formation of $\mathrm{H}_{2} \mathrm{O}(\mathrm{g})(-$ $\left.242 \mathrm{~kJ} \mathrm{~mol}^{-1}\right)$. Further oxidation of $\mathrm{PuN}$ to $\mathrm{Pu}_{2} \mathrm{O}_{3}\left(-529 \mathrm{~kJ} \mathrm{~mol}^{-1} \mathrm{PuN}\right)$ has been reported [1], but neither the rate of $\mathrm{PuN}-\mathrm{O}_{2}$ reaction nor that of ultimate $\mathrm{PuO}_{2}$ formation $(-456 \mathrm{~kJ}$ $\mathrm{mol}^{-1} \mathrm{Pu}_{2} \mathrm{O}_{3}$ ) is described.

Appearance of flame at a discernable distance from the surface during the pyrophoric reaction of hydride suggests that the $\mathrm{H}_{2}-\mathrm{O}_{2}$ reaction is limited by the concentration of oxygen at the gas-solid interface. Both the rate of the $\mathrm{PuH}_{3}$-air reaction (Eqn. 6) and attainment of a flammable mixture for burning of product $\mathrm{H}_{2}$ are apparently controlled by transport through an oxygen-deficient barrier of $\mathrm{N}_{2}$ and $\mathrm{H}_{2}$. In a similar system, the rate of the $\mathrm{Pu}_{2} \mathrm{O}_{3}$-catalyzed oxidation of $\mathrm{Pu}$ in static air at 1 bar increases with temperature below $500^{\circ} \mathrm{C}$, but is constant above that point because diffusion of $\mathrm{O}_{2}$ through an $\mathrm{N}_{2}$-rich layer becomes the slow step [1]. If the $\mathrm{Pu}_{2} \mathrm{O}_{3}$-catalyzed $\mathrm{PuH}_{\mathrm{x}}$-air reaction is sufficiently fast that its rate is controlled by diffusion through a $\mathrm{N}_{2}+\mathrm{H}_{2}$ barrier, the rates of the two reactions should be similar. Division of the rate $\left(0.14 \mathrm{~g} \mathrm{Pu} \mathrm{cm}^{-2} \mathrm{~min}^{-1}\right.$, geom. area) for the diffusion-controlled Pu-air reaction [1] by 20 gives $0.0070 \mathrm{~g} \mathrm{Pu} \mathrm{cm}^{-2} \mathrm{~min}^{-1}$ (BET area), a value consistent with the $0.0051 \mathrm{~g} \mathrm{PuH}_{3} \mathrm{~cm}^{-2} \mathrm{~min}^{-1}$ (BET area) result obtained for Eqn. 2.

Reaction of hydride-coated $\mathrm{Pu}$ with $\mathrm{O}_{2}$ or air undoubtedly proceeds as described for $\mathrm{PuH}_{\mathrm{x}}$ (Eqn. 5), but with increased extents of reaction and heat production due to hydridecatalyzed involvement of the metal. Except for the $\mathrm{PuH}_{\mathrm{x}}$ core, all $\mathrm{Pu}$ is transformed to $\mathrm{Pu}_{2} \mathrm{O}_{3}$ and $\mathrm{PuN}$ with an enthalpy of $-379 \mathrm{~kJ} \mathrm{~mol}^{-1} \mathrm{Pu}$ (or per $0.537 \mathrm{~mol}$ air). If the $\mathrm{Pu}$ surface is partially covered by hydride, the corrosion rate for all hydride-coated areas in air is described by $\mathrm{R}$ (Table 2), but the area-normalized rate is reduced as determined by the fractional hydride coverage of the metal surface. The $\mathrm{PuH}_{\mathrm{x}}$-catalyzed reaction continues until all $\mathrm{Pu}$ is consumed and all hydrogen is present as $\mathrm{PuH}_{3}$. Partial coverage of the metal by hydride is possible because the amounts of hydrogen typically available from chemical and radiolytic sources in storage are small and the formation of $\mathrm{PuH}_{\mathrm{x}}$ is localized by autocatalytic reaction at a limited number of surface sites [1] $\mathrm{H}_{2}$ formed during concurrent reaction of spalled $\mathrm{PuH}_{\mathrm{x}}$ product (Eqn. 7) and partially hydrided $\mathrm{Pu}$ with air does not pressurize the container [2], but reacts with the metal [11].

\section{Conclusions}

Results of this study show that the reaction kinetics of $\mathrm{PuH}_{\mathrm{x}}$ and $\mathrm{PuH}_{\mathrm{x}}$-coated $\mathrm{Pu}$ with $\mathrm{O}_{2}$ and air are described by a single equation with rate constants related by differences between the geometric and BET surface areas of hydride and by consequences of $\mathrm{N}_{2}$ participation as a diluent and as a kinetically neutral reactant. The results imply that the reactions of hydride and metal proceed via the same mechanism. Contrary to an earlier conclusion [2], data evaluation shows that the v-shaped P-t curve observed for the $\mathrm{PuH}_{\mathrm{x}}$-air reaction is due to the combined effect of limited air flow and rapid reaction of air in addition to experimental configuration. $\mathrm{Pu}_{2} \mathrm{O}_{3}$ formed at the hydride surface via Eqn. 5 promotes further reaction by catalyzing dissociation of $\mathrm{O}_{2}$ and transporting the product $\mathrm{O}$ to the oxide-hydride interface. Direct correlation of the rate 
constant for the $\mathrm{PuH}_{\mathrm{x}}$-air reaction with that for the $\mathrm{PuH}_{\mathrm{x}}-\mathrm{O}_{2}$ reaction (Table 2) implies that catalytic $\mathrm{Pu}_{2} \mathrm{O}_{3}$ is formed during exposure of hydride to air or that an oxide nitride product [1] is equally catalytic. $\mathrm{H}$ produced by the ensuing reaction advances into the underlying $\mathrm{PuH}_{\mathrm{x}} \cdot \mathrm{N}_{2}$ in air or other nitrogen-oxygen mixtures participates in the catalyzed reaction by altering the rate of $\mathrm{Pu} / \mathrm{PuH}_{\mathrm{x}}$ consumption without involvement of $\mathrm{P}_{\mathrm{N} 2}$ in the rate equation.

Insight into the pyrophoric nature of $\mathrm{PuH}_{\mathrm{x}}$ has been gained. The reaction initiates spontaneously after exposure of the hydride to air at room temperature because reaction of oxygen immediately forms a $\mathrm{Pu}_{2} \mathrm{O}_{3}$ surface that catalyzes continuing reaction of both $\mathrm{O}_{2}$ and $\mathrm{N}_{2}$. Formation of a gas-phase diffusion barrier during the initial step (Eqn. 5) is precluded by rapid and complete reaction of $\mathrm{N}_{2}$ at a 300-fold faster rate than observed for nitriding of $\mathrm{Pu}$ at $1000{ }^{\circ} \mathrm{C}$ [12]. Although $85 \%$ of the $\mathrm{PuH}_{\mathrm{x}}$ is consumed by $\mathrm{N}_{2}$ during the first step and $\Delta \mathrm{H}^{\mathrm{o}}$ for $\mathrm{PuN}$ formation is $18 \%$ of that for $\mathrm{Pu}_{2} \mathrm{O}_{3}$, the heat flux for catalyzed reaction of $\mathrm{PuH}_{2}$ via Eqn. 5 is 6.5-fold greater than that estimated for catalyzed, but diffusion controlled, oxidation of the dihydride in static air. In large measure, the effectiveness of using $\mathrm{N}_{2}$ dilution methods to reduce hydride pyrophoricity in glovebox atmospheres $[1,8]$ is not only due to the decrease in $\mathrm{O}_{2}$ pressure, but to amplification of the kinetic effect by the dependence of $\mathrm{R}$ on $\left(\mathrm{P}_{\mathrm{O} 2}\right)^{2}$.

The oxidation kinetics of the $\mathrm{PuN}$ and $\mathrm{Pu}_{2} \mathrm{O}_{3}$ products of Eqn. 7 are undefined and the origin of the squared dependence on the $\mathrm{PuH}_{\mathrm{x}}$ oxidation rate on $\mathrm{O}_{2}$ pressure is unknown. Additional investigation is needed to address these deficiencies.

\section{Acknowledgement}

This work was performed under the auspices of the U.S. Department of Energy by Lawrence Livermore National Laboratory under Contract DE-AC52-07NA27344.

\section{References}

1. J.M. Haschke, J.L. Stakebake, The Chemistry of the Actinide and Transuranium Elements, Vol 5, L.R. Morss et al., Eds., Springer, Dordrecht, 2006, pp. 3199-3272.

2. J.M. Haschke, T.H. Allen, J.C.Martz, J. Alloys Compds. 271-273 (1998) 211.

3. J.M. Haschke, T.H, Allen, J. Alloys Compds. 320 (2001) 58.

4. J.M. Haschke, USDOE Report RFP 3099, Rocky Flats Plant, Golden, CO,1981.

5. H.E. Flotow, J.M. Haschke, S. Yamauchi, The Chemistry and Thermodynamics of Actinide Elements and Compounds, Part 9, F.L. Oetting et al. Eds., International Atomic Energy Agency, Vienna, 1984, pp. 49-65.

6. J.M. Haschke, J.L. Stakebake, The Rare Earths in Modern Science and Technology, Vol.2, G.J. McCarthy et al. Eds., Plenum, New York, 1979, 577-582. 
7. J.M. Cleveland, The Chemistry of Plutonium, American Nuclear Society, La Grange Park, IL, 1979.

8. L. N. Dinh, S. K. McCall, C. K. Saw, J. M. Haschke, P. G. Allen, W. McLean II, J. Nuc. Mater. 451 (2014) 143.

9. M. Brierley, J. P. Knowles, A. Sherry, M. Preuss, J. Nucl. Mater. 469 (2016) 145.

10. L.E. Musgrave, USAEC Report, RFP-1566, Rocky Flats Plant, Golden, CO, 1971.

11. J.M. Haschke, J.C. Martz, Los Alamos Science, No. 26 Vol. 1, Los Alamos National Laboratory Los Alamos, NM, 2000, pp. 266-273.

12. F. Brown, H.M. Ockenden, G.A. Welch, J. Chem. Soc., 1955 (1955) 4196. 
Table 1. Equations describing the two-step and the single-step reactions of $\mathrm{PuH}_{2.7}$ and $\mathrm{PuH}_{\mathrm{x}}$ with air. ${ }^{\mathrm{a}}$

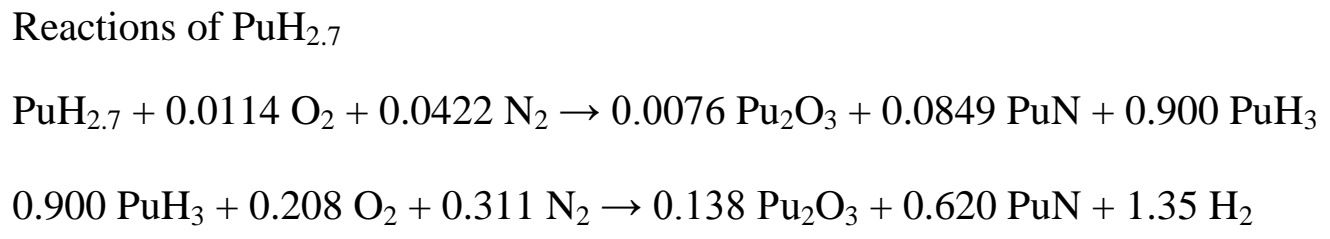

Reactions of $\mathrm{PuH}_{\mathrm{x}}$

$$
\begin{aligned}
& \mathrm{PuH}_{\mathrm{x}}+(0.114-0.038 \mathrm{x}) \mathrm{O}_{2}+(0.423-0.141 \mathrm{x}) \mathrm{N}_{2} \rightarrow(0.075-0.025 \mathrm{x}) \mathrm{Pu}_{2} \mathrm{O}_{3}+ \\
& \text { (0.849-0.283x) PuN + x/3 } \mathrm{PuH}_{3} \text {. (5) } \\
& \mathrm{x} / 3 \mathrm{PuH}_{3}+0.077 \mathrm{x} \mathrm{O}_{2}+0.115 \mathrm{x} \mathrm{N}_{2} \rightarrow 0.051 \mathrm{Pu}_{2} \mathrm{O}_{3}+0.230 \mathrm{PuN}+\mathrm{x} / 2 \mathrm{H}_{2} \text {. } \\
& \mathrm{PuH}_{\mathrm{x}}+(0.114+0.039 \mathrm{x}) \mathrm{O}_{2}+(0.423-0.0264 \mathrm{x}) \mathrm{N}_{2} \rightarrow(0.075+0.026 \mathrm{x}) \mathrm{Pu}_{2} \mathrm{O}_{3}+ \\
& (0.849-0.053 x) \mathrm{PuN}+\mathrm{x} / 2 \mathrm{H}_{2} \text {. } \\
& \mathrm{PuH}_{\mathrm{x}}+0.220 \mathrm{O}_{2}+0.353 \mathrm{~N}_{2} \rightarrow 0.147 \mathrm{Pu}_{2} \mathrm{O}_{3}+0.706 \mathrm{PuN}+\mathrm{x} / 2 \mathrm{H}_{2}
\end{aligned}
$$

a. Eqn. 3 is the sum of Eqns. 1 and 2; Eqn. 7 is the sum of Eqns. 5 and 6. 
Table 2. Comparison of the measured rate constants, $\mathrm{C}$, for the reactions of $\mathrm{PuH}_{\mathrm{x}}$-coated $\mathrm{Pu}$ and $\mathrm{PuH}_{\mathrm{x}}$ with $\mathrm{O}_{2}$ at 1 bar and at 0.21 bar in air. ${ }^{\mathrm{a}}$

\begin{tabular}{|c|c|c|c|}
\hline \multirow{2}{*}{$\begin{array}{l}\text { Gas Phase } \\
\text { (1 bar) }\end{array}$} & \multicolumn{2}{|c|}{ Experimental $\mathrm{C}$} & \multirow[t]{2}{*}{$\mathrm{C}(\mathrm{Pu}): \mathrm{C}\left(\mathrm{PuH}_{\mathrm{x}}\right)$} \\
\hline & $\begin{array}{c}\mathrm{PuH}_{\mathrm{x}} \text {-coated } \mathrm{Pu} \\
(\text { geom. area) }\end{array}$ & $\begin{array}{c}\mathrm{PuH}_{\mathrm{x}} \\
\text { (BET area) }\end{array}$ & \\
\hline $\mathrm{O}_{2}$ & $7.4^{b}$ & 0.37 & 20.2 \\
\hline Air & 1.72 & 0.087 & 19.5 \\
\hline $\mathrm{C}$ (air): $\mathrm{C}\left(\mathrm{O}_{2}\right)$ & 0.23 & 0.24 & \\
\hline
\end{tabular}

a. At each condition, $\mathrm{C}$ (in $\mathrm{g} \mathrm{Pu}$ or $\mathrm{PuH}_{\mathrm{x}} \mathrm{cm}^{-2} \mathrm{bar}^{-2} \mathrm{~min}^{-1)}$ is defined by $\mathrm{R}=\mathrm{C}\left(\mathrm{P}_{\mathrm{O} 2}\right)^{2}$ (geom. or BET area, $\mathrm{P}_{\mathrm{O} 2}$ in bar).

b. The experimental value of $\mathrm{C}$ for the reaction of $\mathrm{PuH}_{\mathrm{x}}$-coated $\mathrm{Pu}$ with $\mathrm{O}_{2}$ at 1 bar is derived from the rate $\left(78.1 \mathrm{~g} \mathrm{Pu} \mathrm{cm}^{-2} \mathrm{~min}^{-1}\right)$ measured at a median $\mathrm{O}_{2}$ pressure of $3.25 \mathrm{bar}$ [2]. 
Table 3. Dependence of $\Delta \mathrm{H}^{\mathrm{o}}$ on $\mathrm{x}$ for step one (Eqns. 5), step two (Eqn. 6), and the net reaction (Eqn. 7) after exposure of $\mathrm{PuH}_{\mathrm{x}}$ to air. ${ }^{\mathrm{a}}$

\begin{tabular}{cccc}
$\mathrm{x}$ & \multicolumn{3}{c}{$\Delta \mathrm{H}^{\mathrm{o}}\left(\mathrm{kJ} \mathrm{mol}^{-1} \mathrm{PuH}_{\mathrm{x}}\right)^{\mathrm{b}, \mathrm{c}}$} \\
& Eqn. 5 & Eqn. 6 & Eqn. 7 \\
2.0 & -104 & -166 & -270 \\
2.7 & -31 & -224 & -255 \\
3.0 & 0 & -248 & -248
\end{tabular}

a. Values are derived using tabulated enthalpies of formation [1].

b. $\Delta \mathrm{H}^{\mathrm{o}}$ values correspond to the sequence of equations formulated per mole of $\mathrm{PuH}_{\mathrm{x}}$ initially reacting via Eqn. 5 (Table 1).

c. Enthalpies for intervening values of $\mathrm{x}$ are determined by interpolation. 


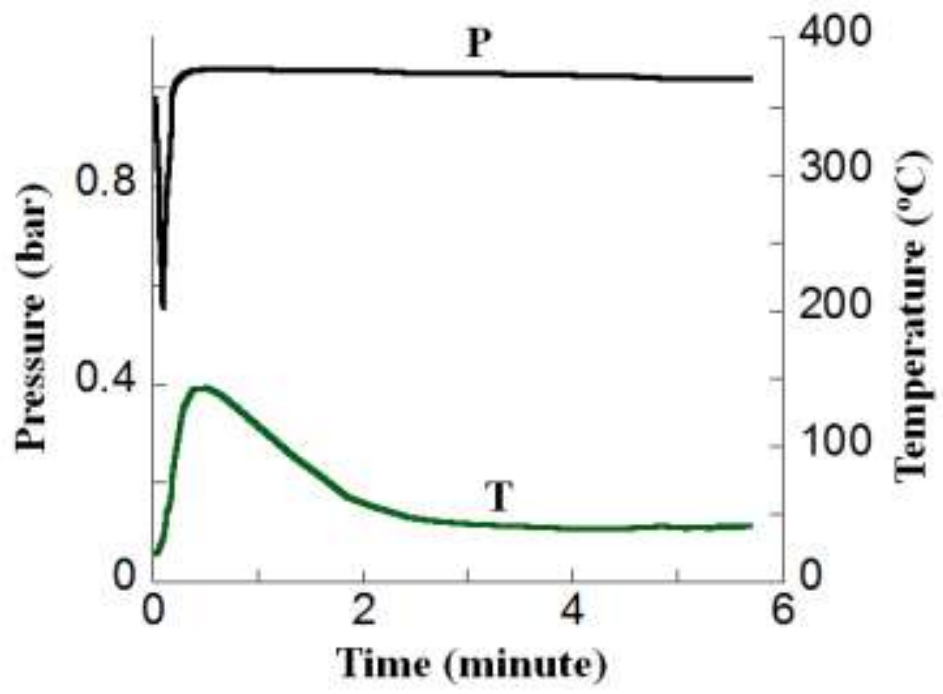

Figure 1. The time dependence of gas pressure and temperature after exposure of $\mathrm{PuH}_{2.7}$ to air at $25^{\circ} \mathrm{C}$ and 1.01 bar. 
Electrons from $\mathrm{PuH}_{\mathrm{x}}(1.9 \leq \mathrm{x}<3)$ catalytically promote dissociative chemisorption of $\mathrm{O}_{2}$ and $\mathrm{N}_{2}$ to form $\mathrm{O}^{2-}$ and $\mathrm{N}^{3-}$ via concerted surface reactions.

Reaction of $\mathrm{O}^{2-}$ and $\mathrm{N}^{3-}$ with $\mathrm{PuH}_{\mathrm{x}}$ forms catalytic $\mathrm{Pu}_{2} \mathrm{O}_{3}, \mathrm{PuN}$, and $\mathrm{H}^{-}$ that moves into the non-stoichiometric hydride and increases $\mathrm{x}$ as electrons from the hydride move to the surface. Reaction proceeds as $\mathrm{Pu}_{2} \mathrm{O}_{3}$ in the product layer catalyzes dissociation of $\mathrm{O}_{2}$ and $\mathrm{N}_{2}$ to form $\mathrm{O}^{2-}$ and $\mathrm{N}^{3-}$ and transport those ions to the $\mathrm{PuH}_{\mathrm{x}}$ interface.

As the $\mathrm{Pu}_{2} \mathrm{O}_{3}+\mathrm{PuN}$ layer grows, reaction of product $\mathrm{H}^{-}(\delta$ moles) with $\mathrm{PuH}_{\mathrm{x}}$ maintains charge balance ( $\delta$ moles $\mathrm{e}^{-}$) and continues until $\mathrm{x}$ $+\delta=3$.

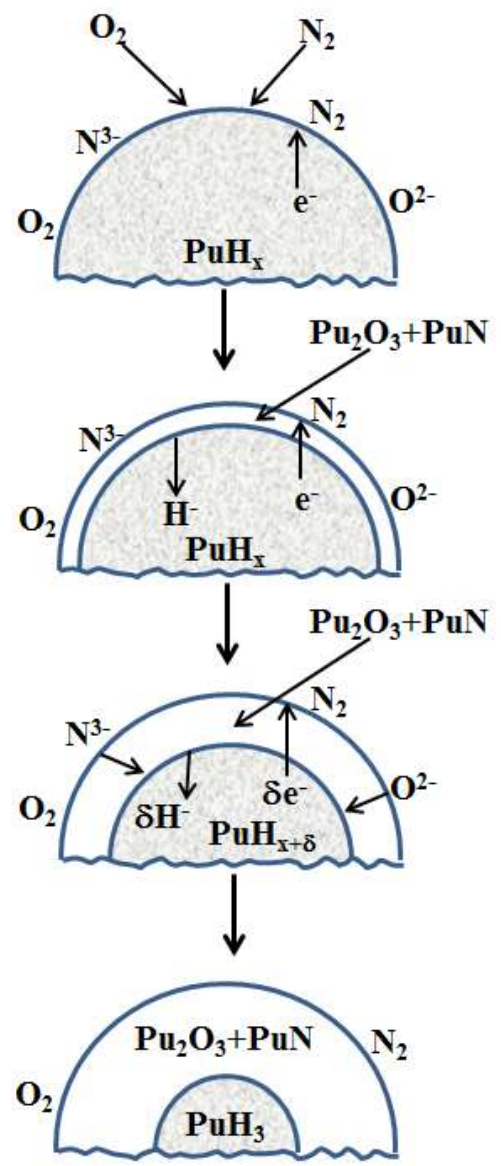

After reaction is complete, each particle has a $\mathrm{PuH}_{3}$ core encased in a $\mathrm{Pu}_{2} \mathrm{O}_{3}+\mathrm{PuN}$ layer with a thickness determined by $\mathrm{x}$ and particle size.

Figure 2. Schematic description of the initial reaction of air with a $\mathrm{PuH}_{\mathrm{x}}$ particle (Eqn.1). A segment of an ideal spherical particle is shown. 